\title{
Effect of adding insulation on the energy performances of rammed earth buildings in hot and arid climates
}

\author{
Wical Cheikhi ${ }^{1, *}$, Khadija Baba $^{1}$, Abderrahman Nounah ${ }^{1}$ and Choukri Cherradi ${ }^{1}$ \\ ${ }^{1}$ GCE Laboratory, High School of Technology - Salé, Mohammed V University- Rabat, Morroco
}

\begin{abstract}
In a world context focused on energy efficiency and sustainable construction, returning to the use of raw earth in construction constitutes a good alternative to concrete construction, a system more energy consuming and yet more used nowadays. This return is justified by the excellent energy performance and the high level of thermal comfort provided by earth constructions in different climates. In cold climates, adding an insulation on earth walls has proven to be effective in improving their thermal performances. However, the influence of adding an insulation on the energy performance of rammed earth buildings in hot and arid climates remains to this day little explored. The present work comes in this order of ideas; it is based on a comparative study of the energetic performances of a mud building before and after the addition of the insulation. In order to compare between their performances, we have performed a simulation of the thermal behaviour of each by the dynamic thermal simulation software Design Builder.
\end{abstract}

\section{Introduction}

Since Antiquity, raw earth remains one of the principal building materials used on our planet. According to the United Nations Center for Human settlements, $40 \%$ of the world's current habitats are earth constructions implanted in different climatic conditions. Although abandoned in favour of other constructive systems, earth constructions are also present in Morocco. They mainly use the technique of rammed earth. Despite their great variety, they have always proved their excellent thermal properties and their ability to maintain comfortable indoor temperatures, both in winter and in summer.

Fortunately, the earth construction knows - in recent years - a new boom in the world thank to its energy performance. In this sense, several authors have been interested in the energy of earth construction in different climates and their supremacy compared to other construction materials. Indeed, Cheikhi et al. [1] led a comparative study between the energy performances of two buildings using two different construction materials: rammed earth on one side, concrete masonry on the other. The results of this study showed a significant decrease in heating requirements for the building built of rammed earth compared to the one built concrete masonry. For its part, Paul et al. [2] compared the comfort of the user in three buildings: one is "green", totally built with the rammed earth technique, the other two "Conventional". Comparing the energy bills of buildings, we note a lower energy consumption in the green building compared to the others. A comparative study between two buildings in Mexico, one in hollow concrete blocks, the other in Adobe was also conducted by Porta-Gandara [3]. The study showed that the energy consumed to maintain a comfortable temperature in the adobe building is 5 times lower than that consumed in the conventional building.

The new expansion of the rammed earth technique is accompanied by its adaptation to modern construction systems. For example, several earthen constructions incorporate wall insulation in order to improve their inertia and their insulation capacity. In this sense, Soebarto \& al. [4] carried out a comparative study of the indoor performance of two rammed earth houses. in Willunga, South Australia: the one uses rammed earth walls and the second uses insulated ones. The results showed that the insulated house could be 5 degrees warmer than the uninsulated one, and would potentially use less energy for heating.

Following the same idea, MA Hall [5] carried out thermal conductivity tests on rammed earth walls with extruded polystyrene insulation. These tests have shown that the combination of a high mass wall with low conductivity insulation provides a wall with lower thermal conductivity than an uninsulated earth wall. These composite walls exhibited excellent thermal properties suitable for a wide range of heating climates. However, the influence of adding an insulation on the energy performance of rammed earth buildings in hot and arid climates has not been much explored. This paper tries to follow this research track. It conducts a comparative study between the energy performances of a rammed earth building before and after the addition of the insulation. The study is based on the thermal dynamic simulation of both variants, led by the software DesignBuilder [6]

\section{Case study description}

We took as a case study a rammed residential building currently under construction in the outskirts of the city of Marrakech. In the following we will diagnose the building and analyze the climatic conditions of its site. these are generated from the climatological database METEONORM [7]

* Corresponding author: author@e-mail.org 


\subsection{Site analysis}
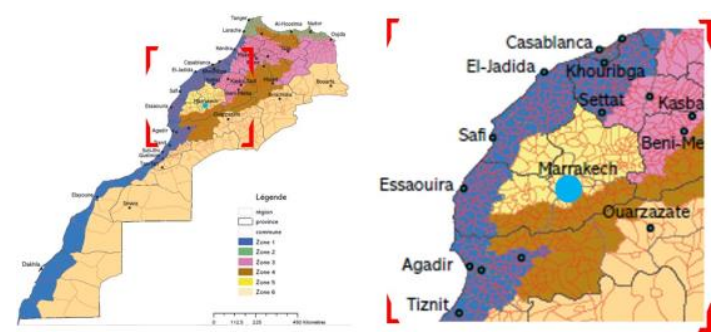

Fig. 1. Location of Marrakech in the climate map of Morocco

Due to its geographical location, the property is part of the climatic zone 5, gathering the city of Marrakech and the surroundings, known to be part of the desert region of southern Morocco.

Table 1. Coordinates of the city of Marrakech

\begin{tabular}{lccc}
\hline & Longitude & Latitude & Altitude \\
\hline Marrakech & $-8,03$ & 31,62 & 463,5 \\
\hline
\end{tabular}

Marrakech is characterized by a hot and arid climate, with high summer temperatures, and temperature differences of up to 15 degrees $\mathrm{C}$ between day and night.

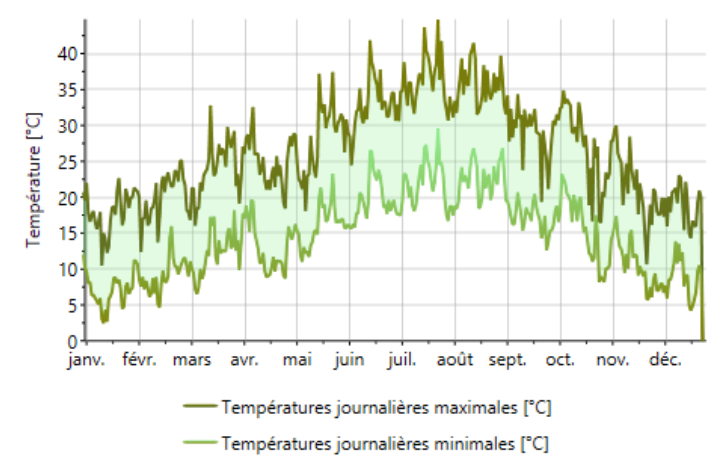

Fig. 2. Annual temperatures of Marrakech

July is the hottest month of the year. The maximum temperature reaches 45 degrees Celsius, the minimum will not drop below 18 degrees Celsius. With 18 degrees Celsius as the maximum temperature and 2 degrees Celsius as the minimum temperature, the month of January remains the coldest of all the year.

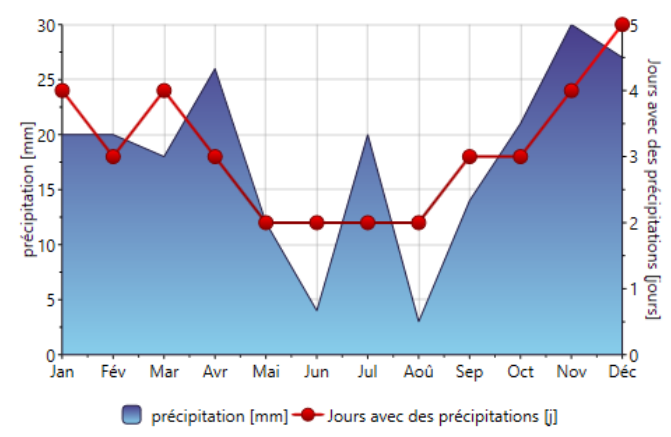

Fig. 3. Average rainfall in Marrakech
Marrakech is characterized by low rainfall. The number of rainy days during the year does not exceed 37 days. The rainiest month of the year is November. It records $30 \mathrm{~mm}$ of rainfall distributed in 5 days.

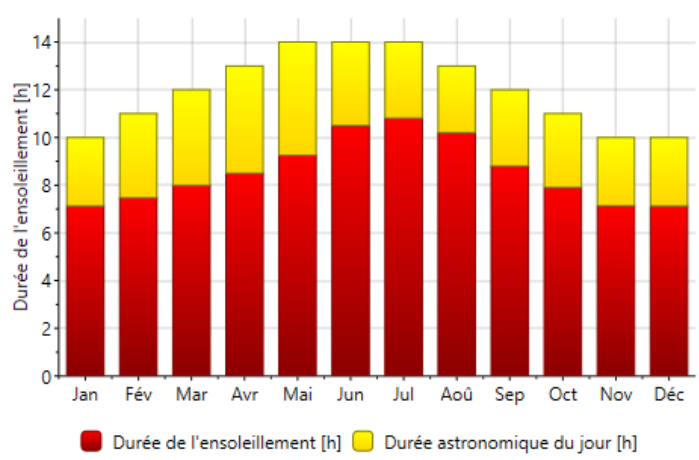

Fig. 4. Duration of sunshine in Marrakech

The maximum duration of sunshine in Marrakech is during the month of July. This duration is 11 hours. The minimum duration, recorded during the months of November, December and January is 7 hours.

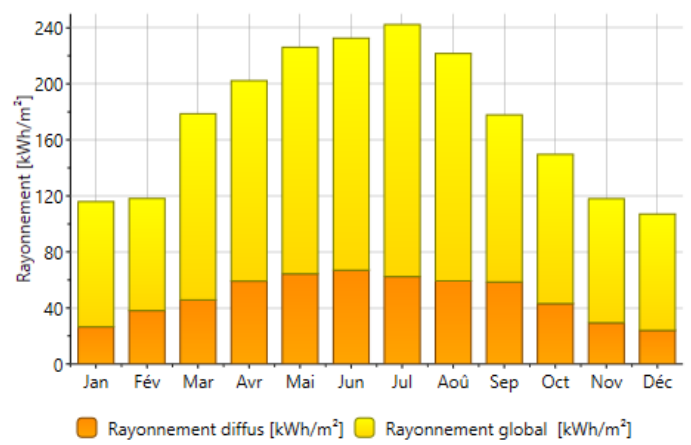

Fig. 5. Global and diffuse radiation in Marrakech

The maximum value of the global radiation is recorded during the month of July. It is $240 \mathrm{kWh} / \mathrm{m}^{2}$. The minimum is noted during the month of December, with a value of $100 \mathrm{kWh} / \mathrm{m}^{2}$. Compared to other Moroccan cities, Marrakech remains a city whose global influence is quite important throughout the year.

\subsection{Description and diagnosis of the building}

The residential building is intended to accommodate a family of 4 persons. With a total surface of $230 \mathrm{~m}^{2}$, the building is spread over two levels: a ground floor, covering an area of $143 \mathrm{~m} 2$, and a first floor of some $90 \mathrm{~m} 2$. The table below summarizes the physical program of the building.

Table 2. Program of the building

\begin{tabular}{lll}
\hline Level & Function & Area \\
\hline & Courtyard & $17 \mathrm{~m} 2$
\end{tabular}




\begin{tabular}{|c|c|c|}
\hline \multirow{5}{*}{ Ground floor } & Kitchen & $16,5 \mathrm{~m} 2$ \\
\hline & Laundry & $6,30 \mathrm{~m} 2$ \\
\hline & Living room & $53,30 \mathrm{~m} 2$ \\
\hline & Room & $11 \mathrm{~m} 2$ \\
\hline & WC & $3 \mathrm{~m} 2$ \\
\hline \multirow[t]{4}{*}{$1^{\text {st }}$ floor } & Master room & $19 \mathrm{~m} 2$ \\
\hline & Bathroom & $3 \mathrm{~m} 2$ \\
\hline & Balcony & $7 \mathrm{~m} 2$ \\
\hline & Courtyard & $39,50 \mathrm{~m} 2$ \\
\hline
\end{tabular}

The building benefits from a North / South orientation. We note a total absence of openings on the east and west facades. The living rooms (bedrooms and living room) are facing south, while the laundry is located in the opposite direction (north). (See plans). This orientation allows the living space to benefit passive solar inputs and create a buffer zone (laundry) protecting the building from heat losses to the north.
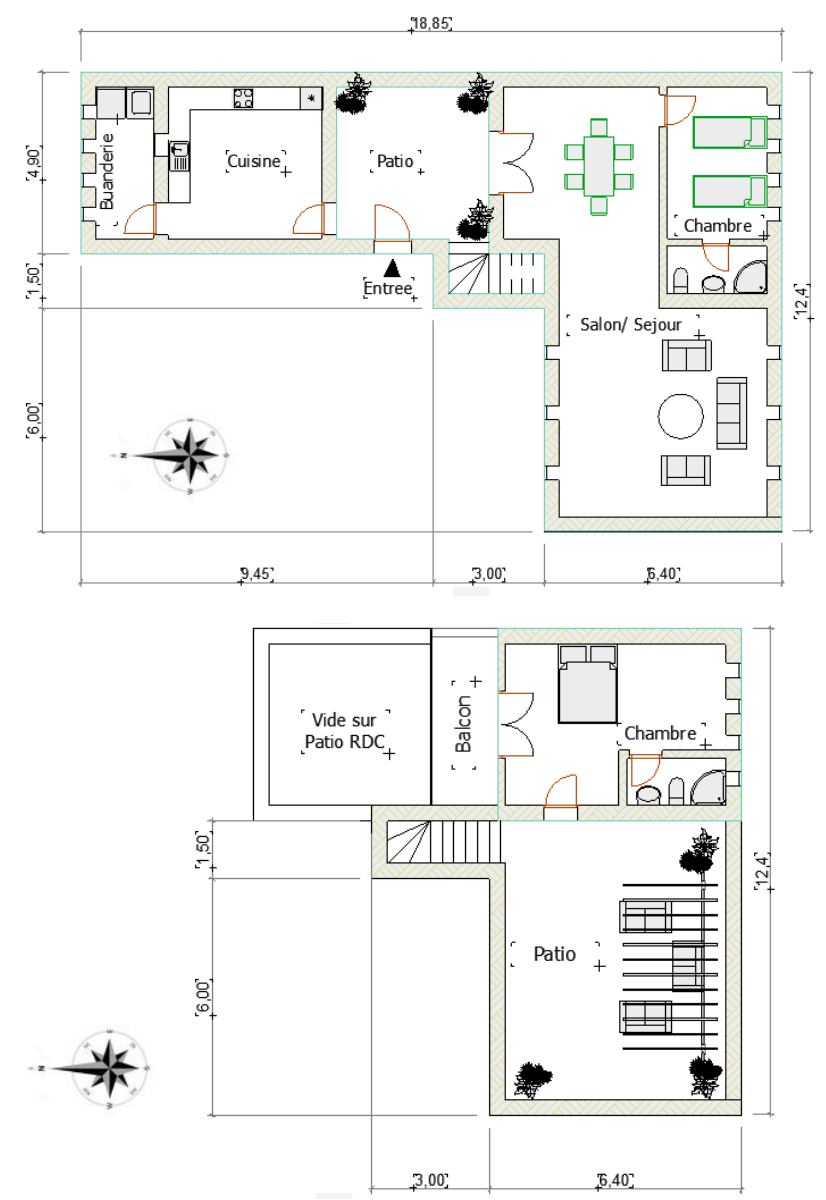

Fig. 7. Building's Layouts
The building has no joint ownership. No shadows are worn on it. Its volum is quite simple: the ground floor is in the form of an L, while the floor is more compact. The volume does not present complex shapes nor makes use of irregular architectonic elements. The building has few corbels, projections and recesses.
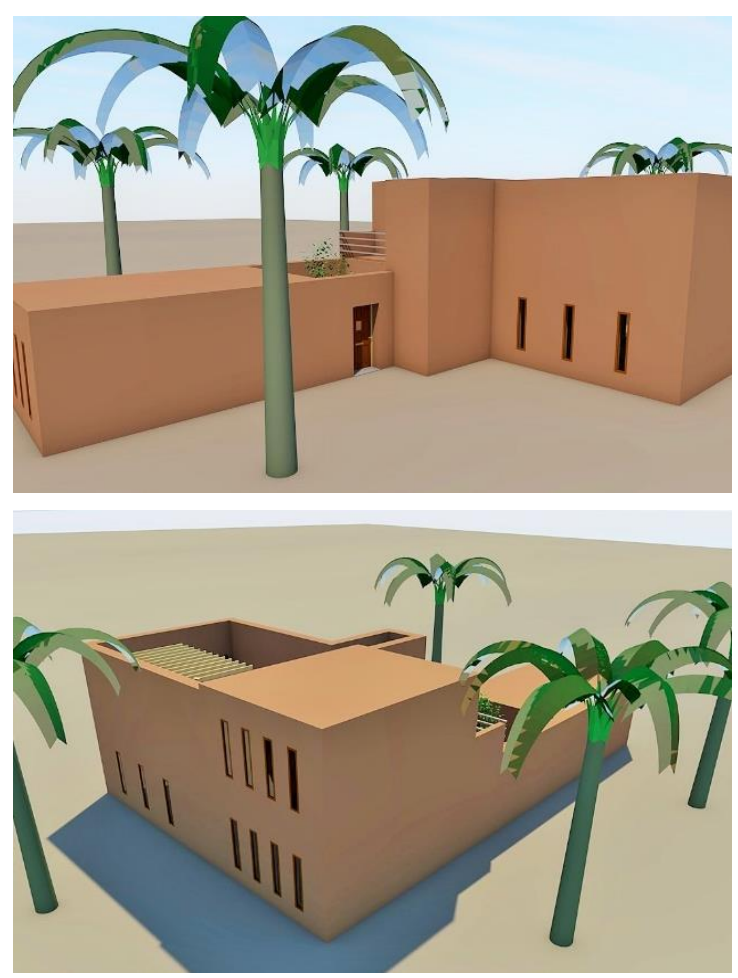

Fig. 8. Building's 3D

The house is built of rammed earth, using the traditional technique of rammed earth. The earth used comes from the region of Marrakech, stabilized with straw. The constitution and the proportions of the mixture are $2 / 3$ of earth for $1 / 3$ of straw. All the outer walls are built with this mixture and are $0,40 \mathrm{~m}$ thick. The high floor is composed of wooden beams, joists and a reed grid.

The thermo-physical characteristics of the material used for the construction of this building were previously the subject of an experimental study [8] led by Lamrani et al. This was based on the asymmetric hot plane method [9] to determine the thermal conductivity $(\lambda)$ and effusivity (e) of the mixture used in the construction of our building, and the flash method [10] to determine its thermal diffusivity (a). The experimental values found and used in our study are summarized in the table below.

Table 3. Thermo physical characteristics of the wall material

\begin{tabular}{|c|c|c|c|c|}
\hline $\begin{array}{l}\text { Thermal } \\
\text { conductivity }\end{array}$ & $\begin{array}{l}\text { Thermal } \\
\text { diffusivity }\end{array}$ & $\begin{array}{l}\text { Thermal } \\
\text { effusivity }\end{array}$ & $\begin{array}{l}\text { Specific } \\
\text { heat }\end{array}$ & $\begin{array}{l}\text { Density } \\
\rho\end{array}$ \\
\hline $\begin{array}{l}\lambda \quad\left(W \cdot m^{-}\right. \\
\left.{ }^{1} \cdot K^{-1}\right)\end{array}$ & $\begin{array}{l}a \cdot 10^{-7} \\
\left(\mathrm{~m}^{2} \cdot \mathrm{s}^{-1}\right)\end{array}$ & $\begin{array}{l}\mathrm{a}\left(\mathrm{w} \cdot \mathrm{s}^{1 / 2} \cdot \mathrm{m}^{-}\right. \\
\left.{ }^{2} \cdot \mathrm{K}^{-1}\right)\end{array}$ & $\begin{array}{l}\text { C (J.Kg- } \\
\left.{ }^{1} \cdot \mathrm{K}^{-1}\right)\end{array}$ & $\left(\mathrm{kg} / \mathrm{m}^{3}\right)$ \\
\hline 0,463 & 3,13 & 648,07 & 1128,59 & 1310,69 \\
\hline
\end{tabular}


The windows used in this building have poor thermal performance. The glazing of the windows is simple, with a thickness of $4 \mathrm{~mm}$. Their thermal characteristics are summarized in the table below:

Table 4. Thermo physical characteristics of the windows

\begin{tabular}{lcccc}
\hline $\begin{array}{l}\text { Glazing } \\
\text { type }\end{array}$ & $\begin{array}{c}\text { Tickness } \\
(\mathrm{mm})\end{array}$ & $\begin{array}{c}\mathrm{Uw} \\
\left(\mathrm{W} / \mathrm{m}^{2}\right.\end{array}$ & $\begin{array}{c}\text { Transparency } \\
(\%)\end{array}$ & $\begin{array}{c}(\mathrm{Fs}) \\
(\%)\end{array}$ \\
\hline $\begin{array}{l}\mathrm{K}) \\
\text { Simple, } \\
\text { clear }\end{array}$ & 4 & 6,00 & 80 & 83 \\
\hline
\end{tabular}

\section{Energy simulation}

In the following, we will proceed to the dynamic thermal simulation of the building. This one will be lead with the thermal dynamic software DESIGN BUILDER. The simulation is done in two stages: first, we will simulate de thermal behavior of the building before the installation of the insulation, then after that. This will allow us to compare its energy performances in both variants and judge the effect that the addition of insulation could have on the performances of a rammed earth building located in a hot and arid zone.

\subsection{Before insulating}

This first thermal simulation will make it possible to define the internal temperatures, the thermal losses as well as the heating and cooling needs of the building object of the study before the addition of the insulation.

The results of the simulation are as follows:

\subsubsection{Heat losses}

These data describe the thermal losses through the various elements of the building.

Table 5. Heat losses

\begin{tabular}{|c|c|c|c|c|}
\hline & Fenster & $\begin{array}{c}\text { External } \\
\text { walls }\end{array}$ & $\begin{array}{c}\text { Intermediate } \\
\text { floor }\end{array}$ & Roof \\
\hline $\begin{array}{c}\text { Heat losses } \\
(\mathrm{kW})\end{array}$ & 3,68 & 4,09 & 0,13 & 1,93 \\
\hline
\end{tabular}

\subsubsection{Thermal comfort}

These data describe the hours of discomfort (summer and winter) recorded in the building.
Table 6. Thermal comfort

\begin{tabular}{l}
$\begin{array}{l}\text { Hours of discomfort per } \\
\text { year }\end{array}$ \\
\hline 5111,55
\end{tabular}

\subsubsection{Heating and cooling demand}

These data describe the energy needs in terms of heating and cooling in the building

Table 7. Heating and cooling demand

\begin{tabular}{ccc}
\hline $\begin{array}{c}\text { Heating } \\
\text { demand } \\
{\left[\mathbf{k W h} / \mathbf{m}^{\mathbf{2}}\right]}\end{array}$ & $\begin{array}{c}\text { Cooling demand } \\
{\left[\mathbf{k W h} / \mathbf{m}^{\mathbf{2}}\right]}\end{array}$ & $\begin{array}{c}\text { Total energy } \\
\text { demand } \\
{\left[\mathbf{k W h} / \mathbf{m}^{\mathbf{2}}\right]}\end{array}$ \\
\hline 35,29 & 690,29 & 725,58 \\
\hline
\end{tabular}

\subsection{After insulating}

This second thermal simulation will make it possible to define the internal temperatures, the thermal losses as well as the heating and cooling needs of the building object of the study after the addition of the insulation.

For this simulation, we undertook three interventions on the building:

- Replace existing windows with better ones

- Apply interior insulation to the walls

- Apply interior insulation on the roof

Here are the characteristics of insulators and windows used:

Table 8. Characteristics of added insulation

\begin{tabular}{|c|c|c|c|c|c|}
\hline & Insulation & $\begin{array}{c}\text { thick } \\
\text { ness } \\
\text { (m) }\end{array}$ & $\begin{array}{c}\lambda \\
(\mathbf{W} \cdot \mathbf{m} \\
\left.{ }^{-1} \cdot K^{-1}\right)\end{array}$ & $\begin{array}{c}\mathrm{C} \\
(\mathbf{J} . \mathrm{Kg} \\
{ }^{-1} \cdot \mathrm{K}^{-1)}\end{array}$ & $\begin{array}{c}\rho \\
\left(\mathrm{kg} / \mathrm{m}^{3}\right. \\
)\end{array}$ \\
\hline Roof & $\begin{array}{l}\text { Mineral } \\
\text { wool }\end{array}$ & 0,05 & 0,04 & 1400 & 15 \\
\hline $\begin{array}{l}\text { Externa } \\
\text { I walls }\end{array}$ & $\begin{array}{c}\text { Expanded } \\
\text { polystyrene }\end{array}$ & 0,05 & 0,038 & 840 & 140 \\
\hline
\end{tabular}

Table 9. Characteristics of the chosen glazing

\begin{tabular}{ccccc}
\hline $\begin{array}{c}\text { Glazing } \\
\text { type }\end{array}$ & $\begin{array}{c}\text { Thickness } \\
(\mathbf{m m})\end{array}$ & $\begin{array}{c}\text { Uw } \\
\left(\mathbf{W} / \mathbf{m}^{2}\right.\end{array}$ & $\begin{array}{c}\text { Transpar } \\
\text { ency }(\%)\end{array}$ & $\mathbf{( F S )}$ \\
& & $\mathbf{K})$ & & \\
\hline $\begin{array}{c}\text { Double } \\
\text { glazing }\end{array}$ & $4-12-4$ & 1,5 & 77 & 65 \\
\hline
\end{tabular}

The simulation results obtained after this intervention are as follows: 


\subsubsection{Heat losses}

These data describe the thermal losses through the various elements of the building, after adding and insulation.

Table 10. Heat losses after adding the insulation

\begin{tabular}{ccccc}
\hline Element & Fenster & $\begin{array}{c}\text { External } \\
\text { walls }\end{array}$ & $\begin{array}{c}\text { Intermediate } \\
\text { floor }\end{array}$ & Roof \\
\hline $\begin{array}{c}\text { Heat losses } \\
(\mathbf{k W})\end{array}$ & 3,32 & 1,97 & 0,04 & 0,74 \\
& & & & \\
\hline
\end{tabular}

\subsubsection{Thermal comfort}

These data describe the hours of discomfort (summer and winter) recorded in the building, after adding an insulation.

Table 11. Thermal comfort after adding the insulation

\section{Hours of discomfort per year}

4667,24

\section{6 months discomfort}

\subsubsection{Heating and cooling demand}

These data describe the energy needs in terms of heating and cooling in the building after adding the insulation.

Table 12. Heating and cooling demand

\begin{tabular}{ccc}
\hline $\begin{array}{c}\text { Heating demand } \\
{\left[\mathbf{k W h} / \mathbf{m}^{\mathbf{2}}\right]}\end{array}$ & $\begin{array}{c}\text { Cooling demand } \\
{\left[\mathbf{k W h} / \mathbf{m}^{\mathbf{2}}\right]}\end{array}$ & $\begin{array}{c}\text { Total } \\
{\left[\mathbf{k W h} / \mathbf{m}^{\mathbf{2}}\right]}\end{array}$ \\
\hline 33.04 & 725,20 & 758,24
\end{tabular}

\subsection{Summary}

\subsubsection{Heat losses}

We note that the thermal losses through the walls, the windows and the roof, decrease significantly following the intervention on the building by the insulation

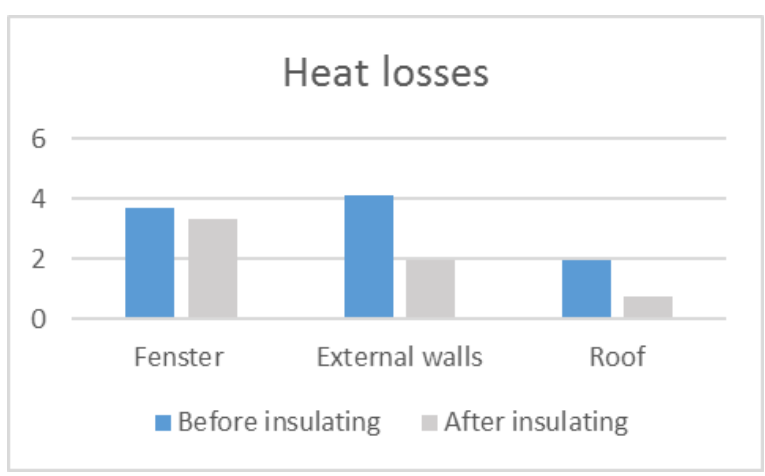

Fig. 9. Heat losses in both variants

\subsubsection{Thermal comfort}

We note that the number of hours of discomfort decreases ostensibly after the intervention on the building

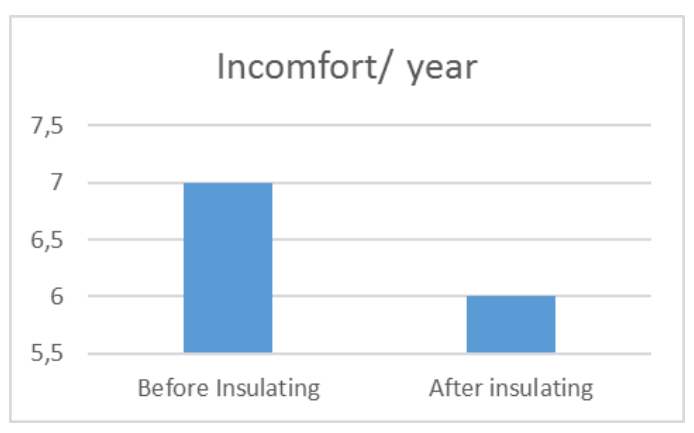

Fig. 10. Hours on incomfort in both variants

\subsubsection{Heating and cooling demand}

We note that the building records an increase of $9.51 \%$ in the total energy needs after the application of the insulation. Despite a decline in heating requirements, the increase is caused by an increase in cooling requirements.

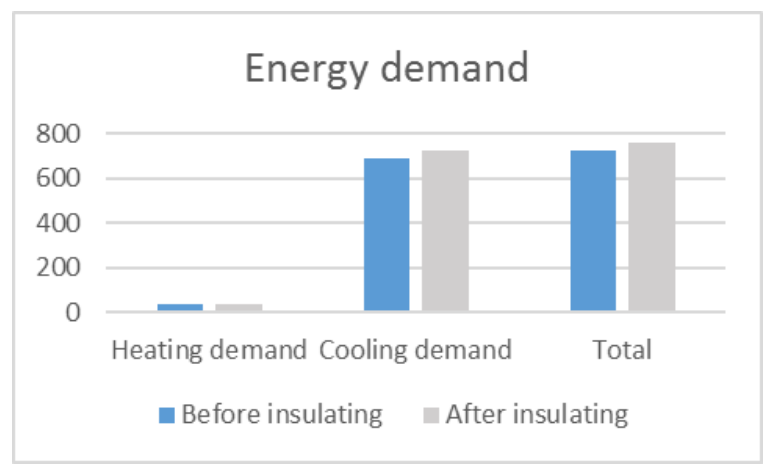

Fig. 11. Energy needs in both variants 


\section{4 conclusion}

Despite a slight decrease in the hours of discomfort and heating needs after the intervention on the building, we note that cooling needs are increasing. This can be explained by the fact that adding the insulation on the walls and the roof led to increase the thermal inertia and the time of phase shift of the walls. Thus, they take longer to restore the heat flow accumulated thereby causing more overheating in summer. These insulation actions - while beneficial for improving heat capture and conservation during winter- increase air conditioning requirements if they are not combined with an efficient ventilation system in the summer.

It can be concluded that the addition of insulation on rammed earth buildings in hot and arid zones does not contribute to improve comfort in summer if not associated to an efficient ventilation system. Alone, it is not recommended for this type of climate.

\section{References}

1. W. Cheikhi, K. Baba, S.M. Lamrani, A. Nounah, M. Khalfaoui, L. Bahi, MATEC Web of Conferences, 149, 02089 (2018)

2. W.L. Paul, P.A. Taylor, Building and Environment 43 (2008)

3. M.A. Porta-Gandara, R. Eduardo, F. Jose Luis, Building and Environment, 37 (2001)

4. V. Soebarto, Eleventh International IBPSA Conference Glasgow, Scotland, 1530-1537 (2009)

5. M.A. Hall, Energ. Build., 40, 2044-2051 (2008)

6. Design Builder Software Ltd. DesignBuilder 2.1 User's Manual (2009). Available at: http://www.designbuilder.co.uk/component/option,c om_docman/task,cat_view/gid,20/Itemid,30/

7. Meteonorm, Global meteoroligal data base, version 7. Software and Data for engineers, planners and education. Version 7.1. (2014)

8. M. Lamrani, PHD Thesis, Mohamed V University, Rabat (2018)

9. Y. Jannot, V. Felix, A. Degiovanni, Measurement Science and Technology, 21 (2010)

10. W. J. Parker, W. J. Jenkins, C. P. Butler, G. L. Abbott, J. App. Physics, 32, 1679-1684 (1961) 